\title{
Promoting Faculty and Student-Centered Research and Innovation based Excellence Model to Reimage Universities
}

\author{
P. S. Aithal ${ }^{1} \&$ Shubhrajyotsna Aithal $^{2}$ \\ ${ }^{1}$ College of Management \& Commerce, Srinivas University, Mangalore - 575 001, India \\ OrcidID: 0000-0002-4691-8736; E-mail: psaithal@gmail.com \\ ${ }^{2}$ Dept. of Chemistry, College of Engineering \& Technology, Srinivas University, Mangalore- \\ 575001, India \\ OrcidID: 0000-0003-1081-5820; E-mail: shubhraaithal@gmail.com
}

Area/Section: Education Management.

Type of the Paper: Research Paper.

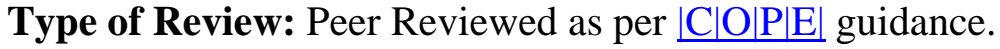

Indexed in: OpenAIRE.

DOI: http://doi.org/10.5281/zenodo.3702399.

Google Scholar Citation: IJMTS.

How to Cite this Paper:

Aithal, P. S., \& Aithal, Shubhrajyotsna. (2020). Promoting Faculty and Student-Centered Research and Innovation based Excellence Model to Reimage Universities. International Journal of Management, Technology, and Social Sciences (IJMTS), 5(1), 24-42.

DOI: $\underline{\text { http://doi.org/10.5281/zenodo.3702399. }}$

International Journal of Management, Technology, and Social Sciences (IJMTS)

A Refereed International Journal of Srinivas University, India.

(C) With Authors.

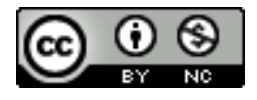

This work is licensed under a Creative Commons Attribution-Non-Commercial 4.0 International License subject to proper citation to the publication source of the work.

Disclaimer: The scholarly papers as reviewed and published by the Srinivas Publications (S.P.), India are the views and opinions of their respective authors and are not the views or opinions of the SP. The SP disclaims of any harm or loss caused due to the published content to any party. 


\title{
Promoting Faculty and Student-Centered Research and Innovation based Excellence Model to Reimage Universities
}

\author{
P. S. Aithal ${ }^{1}$ \&Shubhrajyotsna Aithal $^{2}$ \\ ${ }^{1}$ College of Management \& Commerce, Srinivas University, Mangalore - 575 001, India \\ OrcidID: 0000-0002-4691-8736; E-mail: psaithal@gmail.com \\ ${ }^{2}$ Dept. of Chemistry, College of Engineering \& Technology, Srinivas University, Mangalore- \\ 575001, India \\ OrcidID: 0000-0003-1081-5820; E-mail: shubhraaithal@gmail.com
}

\begin{abstract}
Universities worldwide facing a dilemma in identifying effective models of improving the quality education to their students at UG and PG levels in order to inculcate employable skills and innovative abilities as per industry requirement. Industries and industry sectors also struggling to identify young graduates who can be innovators to add new ideas and models to add values to their existing products and services to survive, sustain and differentiate in present business competition. This, in turn, developing pressure on Universities to re-define their education models including, suitable subject identification, developing and offering industry related curriculum, effective teaching - learning methodologies including suitable customized pedagogy and use of educational technology to boost the confidence and innovative thinking abilities of graduates. In this paper, we have made an attempt to analyse the present trend in global Higher Education, their effect on Indian University education, technology and its impact on university education model, how research can differentiate campus based university education, Innovations in University research including author centric scholarly publication for copyright based IPR and Student Centric Curriculum for Patent Based IPR. The paper also proposed a model of promoting research at UG and PG levels boosts the Innovative ability of students and faculty members towards excellency. Finally, the authors made some recommendations to reimage the universities towards world-class universities.
\end{abstract}

Keywords: Reimaging the universities, Promoting research, Promoting innovation, Promoting excellence in higher education.

\section{INTRODUCTION :}

Higher education institutions worldwide are engaged in providing scientific education systematically through teaching-learning and research processes to empower youths by providing, knowledge, skills, values, and experience so that they get enhanced confidence to identify and solve problems in society. Recently it is observed that many Universities globally facing a dilemma in identifying effective models of improving the quality education to their students at UG and PG levels in order to inculcate employable skills and innovative abilities as per industry requirement.
Industries and industry sectors also struggling to identify young graduates who can be innovators to add new ideas and models to add values to their existing products and services to survive, sustain and differentiate in present business competition. This, in turn, developing pressure on Universities to re-define their education models including, suitable subject identification, developing and offering industry related curriculum, effective teaching - learning methodologies including suitable customized pedagogy and use of educational technology to boost the confidence and innovative thinking abilities of graduates.

Further, it is also observed that every University 
is struggling for its existence, survival, and growth, and continuously plan and implement its generic and specific strategies for continuous improvement. Apart from generic strategies used in Higher Educations Institutions (HEI) which include survival [1], sustainability [2], differentiation [3], monopoly [4], and growth \& expansion, [5], Universities have to adopt specific strategies to be locally engaged and globally visible [6], which include : (1) Adoption of flexible and customized model of education for internet-generation (iGen/Gen Z) students, (2) Open system including open source software and hardware usage to do collaborative projects related to real world challenges, (3) Offering innovative super specialty courses at UG and PG levels in collaboration with industries (industry integrated programmes) and entrepreneurship to nurture experience seeking and enterprising mindset of students, (4) Identifying local problems and involving in solving them through cross-border university public-private partnership which can be later scalable to global level, (5) Encouraging and empowering faculty members with global mindset and global technology. This also needs an open-minded visionary leader in the university as a role-model involving for both teaching-learning innovations and researchbased innovations.

In this paper, we have made an attempt to analyse the present trend in global Higher Education, their effect on Indian University education, technology and its impact on university education model, how research can differentiate campus based university education, Innovations in University research including author centric scholarly publication for copyright based IPR and Student Centric Curriculum for Patent Based IPR. The paper also proposed a model of promoting research at UG and PG levels boosts the Innovative ability of students and faculty members towards excellency. Finally, the authors made some recommendations to reimage the universities towards world-class universities.

\section{A GLANCE ON UNIVERSITIES IN INDIA :}

In India, as per 2018-19 AISHE survey, the total enrolment for higher education with age group 18-23 is 3.74 crores and the Gross Enrolment Ratio (GER) is approximately $26.3 \%$. There are 993 Universities, 39,931 Colleges, and 10725 Stand Alone Institutions are officially listed. Out of them as on $01 / 02 / 2020$, as per University Grant Commission (UGC) of India, there are 935 functioning Universities with 409 State Universities, 50 Central Universities, 127 Deemed to be Universities, and 349 State Private Universities. As per our survey using their websites, state private universities are found to be more innovative and challenge seekers in terms of starting new industryoriented skill-based job specific courses both at undergraduate (UG) and postgraduate (PG) levels. This is because State private universities in India have better autonomy to start new innovative courses compared to deemed to be universities, State public universities, and central universities as shown in Table 1.

Table 1 : Use of autonomy to impart academic freedom to start new innovative courses in different types of universities in India

\begin{tabular}{|l|l|l|}
\hline $\begin{array}{l}\text { S. } \\
\text { No. }\end{array}$ & $\begin{array}{l}\text { Type of } \\
\text { Universities }\end{array}$ & $\begin{array}{l}\text { Autonomy used for } \\
\text { Innovation in starting } \\
\text { new } \\
\text { oriented courses }\end{array}$ \\
\hline 1 & $\begin{array}{l}\text { State Public } \\
\text { Universities }\end{array}$ & $\begin{array}{l}\text { Low level Autonomy } \\
\text { due to less academic } \\
\text { freedom in a } \\
\text { conservative setup, } \\
\text { low financial freedom, } \\
\text { high control by higher } \\
\text { education professional } \\
\text { councils, substantially } \\
\text { low decision-making } \\
\text { freedom by foreseeing } \\
\text { the future. }\end{array}$ \\
\hline 2 & $\begin{array}{l}\text { Medium Autonomy } \\
\text { due to less academic } \\
\text { freedom in a } \\
\text { conservative setup, } \\
\text { medium level financial } \\
\text { freedom, no control by }\end{array}$ \\
\hline
\end{tabular}




\begin{tabular}{|l|l|l|}
\hline & & $\begin{array}{l}\text { higher education } \\
\text { professional councils, } \\
\text { Quick decision-making } \\
\text { freedom by foreseeing } \\
\text { the future but internal } \\
\text { Bureaucratic control. }\end{array}$ \\
\hline 3 & $\begin{array}{l}\text { Deemed to be } \\
\text { Universities }\end{array}$ & $\begin{array}{l}\text { High level Autonomy } \\
\text { due to high academic } \\
\text { freedom, high financial } \\
\text { freedom, high control } \\
\text { by higher education } \\
\text { professional councils, } \\
\text { average level of } \\
\text { decision-making } \\
\text { freedom by foreseeing } \\
\text { the future. }\end{array}$ \\
\hline 4 & $\begin{array}{l}\text { Sery high due to high } \\
\text { academic freedom, } \\
\text { Universities } \\
\text { Privaucratic freedom, } \\
\text { Financial freedom, } \\
\text { Low control by Higher } \\
\text { education professional } \\
\text { Councils, Quick } \\
\text { decision-making } \\
\text { freedom by foreseeing } \\
\text { the future }\end{array}$ \\
\hline
\end{tabular}

India, being a democratic country, gives equal importance to public and private universities. Before year 2,000 India has not opened up its education policy to start State private universities and during the last 20 years it has opened up for state private universities along with many private deemed to be universities. Presently, India is enjoying the second position in terms of the number of private universities in the world as on date with 349 state private universities and 129 private deemed to be universities as shown in table 2. The state universities affiliate many colleges either region wise or professional subject area wise, whereas central universities, deemed to be universities, and state private universities are standalone institutions.

Table 2 : Ranking of countries based on number of private universities [7].

\begin{tabular}{|c|c|c|c|}
\hline $\begin{array}{l}\text { Rank } \\
\text { No. }\end{array}$ & Country & Continent & $\begin{array}{l}\text { Number of } \\
\text { Private } \\
\text { Universities }\end{array}$ \\
\hline 1 & Japan & Asia & $700^{*}$ \\
\hline 2 & India & Asia & 478 \\
\hline 3 & Poland & Europe & 321 \\
\hline 4 & $\begin{array}{l}\text { United } \\
\text { States }\end{array}$ & America & $\begin{array}{c}100 \\
\text { (Approximate) }\end{array}$ \\
\hline 5 & Pakistan & Asia & 83 \\
\hline 6 & German & Europe & 83 \\
\hline 7 & Malaysia & Asia & 66 \\
\hline 8 & Turkey & Europe & 66 \\
\hline 9 & Nigeria & Africa & 60 \\
\hline 10 & Thailand & Asia & 37 \\
\hline
\end{tabular}

* In Japan all higher education institutions which offer undergraduate and postgraduate courses are autonomous and called Universities.

\section{RELATED WORK :}

Many research works have been published in the area of reimaging universities and other higher education institutions innovative practices in academic teaching - learning and research contributions of students and faculty members to contribute to new knowledge and to create new products or processes. Some of the related scholarly research papers published during recent years with the focus of research are listed in table 3.

Table 3 : Review of related scholarly research work

\begin{tabular}{|l|l|l|l|}
\hline $\begin{array}{l}\text { S. } \\
\text { No. }\end{array}$ & Area based on Keywords & Focus of Research & References \\
\hline 1 & $\begin{array}{l}\text { Research based reimaging } \\
\text { of universities }\end{array}$ & $\begin{array}{l}\text { Research Universities, Innovation, } \\
\text { and Growth }\end{array}$ & Suresh, S. (2015) [8] \\
\hline 2 & $\begin{array}{l}\text { Research based reimaging } \\
\text { of universities }\end{array}$ & $\begin{array}{l}\text { University-industry relationships } \\
\text { and open innovation as a research } \\
\text { agenda }\end{array}$ & $\begin{array}{l}\text { Perkmann, M. et al. (2007) } \\
\text { [9] }\end{array}$ \\
\hline 3 & $\begin{array}{l}\text { Research based reimaging } \\
\text { of universities }\end{array}$ & The future of research universities & Rip A. (2011). [10] \\
\hline 4 & Research based reimaging & Create the university of the future & Quinsee S. (2011). [11] \\
\hline \hline
\end{tabular}


International Journal of Management, Technology, and Social

\begin{tabular}{|c|c|c|c|}
\hline & of universities & & \\
\hline 5 & $\begin{array}{l}\text { Innovation based } \\
\text { reimaging of universities }\end{array}$ & $\begin{array}{l}\text { A model of adoption of innovation } \\
\text { within universities }\end{array}$ & Hariri A. et al. (2015). [12] \\
\hline 6 & $\begin{array}{l}\text { Innovation based } \\
\text { reimaging of universities }\end{array}$ & $\begin{array}{l}\text { A fuzzy-set approach for MOOC- } \\
\text { intensiveness on innovation at } \\
\text { universities }\end{array}$ & $\begin{array}{l}\text { Ospina-Delgado et al. (2016). } \\
\text { [13] }\end{array}$ \\
\hline 7 & $\begin{array}{l}\text { Innovation based } \\
\text { reimaging of universities }\end{array}$ & $\begin{array}{l}\text { Open innovation in universities and } \\
\text { the relationship between innovation } \\
\text { and commercialization }\end{array}$ & $\begin{array}{l}\text { Abdul Razak, A. et al. } \\
\text { (2014). [14] }\end{array}$ \\
\hline 8 & $\begin{array}{l}\text { Innovation based } \\
\text { reimaging of universities }\end{array}$ & $\begin{array}{l}\text { Quality teaching practices in higher } \\
\text { education- some cases }\end{array}$ & Salter, D. J. (2013). [15] \\
\hline 9 & $\begin{array}{l}\text { Excellence based } \\
\text { reimaging of universities }\end{array}$ & $\begin{array}{l}\text { The university, accountability, and } \\
\text { market discipline in the late 1990s }\end{array}$ & $\begin{array}{l}\text { Sosteric, M. et al. (1998). } \\
\text { [16] }\end{array}$ \\
\hline 10 & $\begin{array}{l}\text { Excellence based } \\
\text { reimaging of universities }\end{array}$ & $\begin{array}{l}\text { Strategic Direction towards } \\
\text { Internationalization Business and } \\
\text { Management Education }\end{array}$ & Kusumastuti, D. (2013). [17] \\
\hline 11 & $\begin{array}{l}\text { Excellence based } \\
\text { reimaging of universities }\end{array}$ & $\begin{array}{l}\text { Reimagining teaching excellence } \\
\text { by means of collaboration rather } \\
\text { than competition, to improve } \\
\text { teaching and learning in higher } \\
\text { education }\end{array}$ & $\begin{array}{l}\text { O’Leary, M. et al. (2019). } \\
\text { [18] }\end{array}$ \\
\hline 12 & $\begin{array}{l}\text { Excellence based } \\
\text { reimaging of universities }\end{array}$ & $\begin{array}{l}\text { Transforming edict to ethic for } \\
\text { reimagining excellence in inclusive } \\
\text { education }\end{array}$ & Freytag, C. E. (2008). [19] \\
\hline 13 & $\begin{array}{l}\text { Excellence based } \\
\text { reimaging of universities }\end{array}$ & $\begin{array}{l}\text { Reimagining, reassembling and } \\
\text { reinventing the public university }\end{array}$ & Lewis, N. et al. (2019). [20] \\
\hline 14 & $\begin{array}{l}\text { Excellence based } \\
\text { reimaging of universities }\end{array}$ & $\begin{array}{l}\text { Problem Based Learning and the } \\
\text { University of the Future for } \\
\text { developing 21st Century Skills }\end{array}$ & $\begin{array}{l}\text { Kek, M. Y. et al. (2015). } \\
\text { [21] }\end{array}$ \\
\hline
\end{tabular}

4. OBJECTIVES, AGENDA \& (5) To propose a model of promoting research METHODOLOGY : at UG and PG levels to boost the Innovative

The objectives of the current conceptual research include the following :

(1) To analyze the present trend in global Higher Education, their effect on Indian University education,

(2) To review the scholarly research on reimaging the universities based on research, innovation, and excellence.

(3) To monitor the effect of technology and its impact on university education model,

(4) To argue how research \& innovation can differentiate campus-based university education, including author centric scholarly publication for copyright based IPR and Student Centric Curriculum for Patent Based IPR. ability of students and faculty members towards excellency.

(6) To make some recommendations based on findings to reimage the universities towards world-class universities.

This conceptual research made use of data from primary sources including university and HE institutions website and secondary data from various publications and research database including google scholar, ResearchGate, and Elsevier's SSRN. The postulates are developed using predictive analysis methodology on collected data and information [22] and do not need testing.

\section{TECHNOLOGY AND ITS IMPACT ON UNIVERSITY EDUCATION MODEL :}

Innovations in higher education are of two 
kinds: technology driven innovation and creativity \& cleverness driven innovation. In technology driven innovation, the education system including the mode of offer, pedagogy, training, assessment, and evaluation are heavily depends on prevailing technology. As technology progress, the education model becomes more and more innovative and learner friendly. Table 4 depicts the impact of technology on industrial progress and table 5 depicts the impact of technology on education as a service industry. Use of technology in the education industry also depends on the generation time and technology available for the learners at that time. Table 6 identifies the various generations available currently in the society along with their born period, hobbits and relevant education technology used. From table 4 , it can be seen that the current industry 4.0 focuses on mass customization by means of cyber-physical systems using technologies like the internet of things (IoT) and 3D printing. Based on predictive analysis, we propose the next industry revolution called industry 5.0 with objective of Mass Automation and 3D production using Nanotechnology and ICCT controlled Super Intelligent Machines. ICCT has twelve identified underlying technologies that include Artificial intelligence technology, Blockchain technology, Big data and business intelligence, Cloud computing, Cyber security, 3-D printing, Internet of Things (IoT) technology, Information storage technology, Mobile marketing technology, Online education technology, Quantum computing, and Augmented and virtual reality [23-24].

Table 4 : Technology impact on Industry

\begin{tabular}{|l|l|l|l|}
\hline S. No. & $\begin{array}{l}\text { Progress of } \\
\text { Industry }\end{array}$ & Characteristics & Technology used \\
\hline 1 & Industry 1.0 & Mechanization - Energy based. & Water \& Steam Power Systems \\
\hline 2 & Industry 2.0 & $\begin{array}{l}\text { Mass Production - Knowledge } \\
\text { based. }\end{array}$ & Electricity and assembly line \\
\hline 3 & Industry 3.0 & $\begin{array}{l}\text { Automation Processes - Skill } \\
\text { based. }\end{array}$ & $\begin{array}{l}\text { Computer and Communication } \\
\text { technology }\end{array}$ \\
\hline 4 & Industry 4.0 & $\begin{array}{l}\text { Mass Customization - Experience } \\
\text { based. }\end{array}$ & $\begin{array}{l}\text { Internet of Things (IoT) and 3D } \\
\text { printing }\end{array}$ \\
\hline 5 & $\begin{array}{l}\text { Industry 5.0 } \\
\text { (Predicted) }\end{array}$ & $\begin{array}{l}\text { Mass Automation and 3D } \\
\text { production using Nanotechnology } \\
\text { and ICCT controlled Super } \\
\text { Intelligent Machine systems - } \\
\text { Intelligence based. }\end{array}$ & $\begin{array}{l}\text { ICCT underlying technologies } \\
\text { including Artificial intelligence \& } \\
\text { Virtual reality and Nanotechnology }\end{array}$ \\
\hline
\end{tabular}

Table 5 : Technology impact on education industry

\begin{tabular}{|c|c|c|c|}
\hline $\begin{array}{l}\text { S. } \\
\text { No. }\end{array}$ & $\begin{array}{l}\text { Progress of Education } \\
\text { Industry }\end{array}$ & Characteristics & Technology used \\
\hline 1 & Education 1.0 & $\begin{array}{l}\text { Reading \& writing - Information } \\
\text { accumulation. }\end{array}$ & $\begin{array}{l}\text { Letters using ink on paper or } \\
\text { Palm leaf }\end{array}$ \\
\hline 2 & Education 2.0 & $\begin{array}{l}\text { Reading and understanding - } \\
\text { Knowledge based study. }\end{array}$ & $\begin{array}{l}\text { Paper \& Book based type written } \\
\text { knowledge } \\
\text { technology }\end{array}$ \\
\hline 3 & Education 3.0 & $\begin{array}{l}\text { Automated mass learning using } \\
\text { MOOC- Skill based training. }\end{array}$ & $\begin{array}{lcc}\text { Computer, } & \text { storage } & \text { and } \\
\text { Communication technology } & \\
\end{array}$ \\
\hline 4 & Education 4.0 & $\begin{array}{l}\text { Mass Customization using } \\
\text { research and innovation - } \\
\text { Experience based learning. }\end{array}$ & $\begin{array}{l}\text { MOOC Internet of Things (IoT) } \\
\text { based digital technologies }\end{array}$ \\
\hline
\end{tabular}




\begin{tabular}{|l|l|l|l|}
\hline 5 & Education 5.0 & $\begin{array}{l}\text { Mass Automation using } \\
\text { Nanotechnology and ICCT } \\
\text { controlled Super Intelligent } \\
\text { including Artificial intelligence \& } \\
\text { Machine systems - Intelligence } \\
\text { based. }\end{array}$ & \begin{tabular}{l} 
Nanotechnology reality and \\
\hline
\end{tabular} \\
\hline
\end{tabular}

Table 6 : Habits and frequently use education technology of various generations

\begin{tabular}{|c|c|c|c|c|}
\hline $\begin{array}{l}\text { S. } \\
\text { No. }\end{array}$ & Generation & Born Period & Habits & $\begin{array}{l}\text { Frequently used Education } \\
\text { Technology }\end{array}$ \\
\hline 1 & $\begin{array}{l}\text { Silent Generation } \\
\text { (or Traditionalist) }\end{array}$ & $1930-1944$ & $\begin{array}{l}\text { Read News Paper, Cash } \\
\text { \& Barter transactions }\end{array}$ & $\begin{array}{l}\text { Black Slate and Processed dry } \\
\text { leaf for writing \& } \\
\text { communication }\end{array}$ \\
\hline 2 & Boomers & $1945-1964$ & $\begin{array}{l}\text { Watch Radio, Branch } \\
\text { banking, use cash for } \\
\text { small transactions }\end{array}$ & $\begin{array}{l}\text { Paper based notebook for } \\
\text { information gathering, writing } \\
\text { \& communication }\end{array}$ \\
\hline 3 & Generation X & $1965-1979$ & 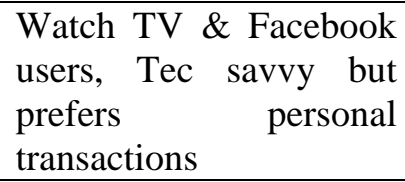 & $\begin{array}{lrr}\text { Xerox } & \text { /Copying } & \text { for } \\
\text { information } & \text { storage } & \text { and } \\
\text { telephone technology } & \text { for } \\
\text { communication } & \end{array}$ \\
\hline 4 & $\begin{array}{l}\text { Generation Y (or } \\
\text { Millennials) }\end{array}$ & $1980-1994$ & $\begin{array}{l}\text { Cable based } \\
\text { Internet } \\
\text { transactions }\end{array}$ & $\begin{array}{l}\text { Computer based copying, } \\
\text { scanning, Processing \& wired } \\
\text { internet technology for } \\
\text { communication }\end{array}$ \\
\hline 5 & $\begin{array}{l}\text { Generation Z } \\
\text { (or iGen } \\
\text { Centennials) } \\
\end{array}$ & $1995-2015$ & $\begin{array}{l}\text { Mobile devices, Online } \\
\text { games, Mobile banking }\end{array}$ & $\begin{array}{l}\text { Online books \& Internet based } \\
\text { information \& communication } \\
\text { using mobile devices }\end{array}$ \\
\hline 6 & $\begin{array}{l}\text { Generation A } \\
\text { (Artificial } \\
\text { intelligence } \\
\text { generation) }\end{array}$ & $\begin{array}{l}2016 \\
\text { onwards }\end{array}$ & $\begin{array}{lr}\text { Artificial } & \text { Intelligence } \\
\text { and virtual } & \text { reality } \\
\text { embedded } & \text { mobile } \\
\text { devices } & \end{array}$ & $\begin{array}{l}\text { Intelligent machines \& super } \\
\text { intelligent machine based } \\
\text { virtual reality \& Augmented } \\
\text { virtual reality educating } \\
\text { technology models }\end{array}$ \\
\hline
\end{tabular}

The present-day students in Universities are belonging to generation $\mathrm{Z}$ as derived from table 6 , and they have the habit of using mobile devices for information communication, play online games using mobile devices and do online financial transactions using mobile devices. They use online books \& Internet based information \& communication technology using mobile devices. Accordingly, higher education offered by the universities have to change their curriculum, pedagogy, and models to be suitable for generation $\mathrm{Z}$. Generation $\mathrm{Z}$ is introduced to online internet based learning [25] and hence called net generation [26-27]. They are comfortable in digital supported learning using mobile devices [28-30].

Similarly, the next generation entering to the higher education system soon are belonging to Generation A or Artificial intelligence generation with the habit of using artificial intelligence and virtual reality embedded mobile devices as their learning medium. To provide suitable higher education for current and future generations universities should redefine their education system so that they can become relevant. Adopting artificial intelligence in education system provides an easy way of knowledge management and redefines teachinglearning process and evaluation system more learner friendly and avoids the importance of memorizing or byhearting many things simultaneously for the examination. The augmented and virtual reality technology allows the learners to solve problems or to visualize the 
possible solutions virtually and allows to determine various dimensions of a problem without spending tangible resources in reality. Though Generation S, Generation B, Generation $\mathrm{X}$, Generation $\mathrm{Y}$, and Generation $\mathrm{Z}$ are available in the literature, Generation A is introduced first time here to represent the people born after 2015 and is the witness of developments in artificial intelligence and other ICCT underlying technologies in daily life as well as in their education process. Higher educational institutions are being transformed by intelligent systems that are helping students to learn better by achieving their learning objectives. The areas of artificial intelligence including intelligent tutors, personalized trainers, smart advisors, learning analytics, are already achieved. Potentially, AI techniques are less expensive and more effective to higher education and contributing to improve learning outcomes and helping institutions to provide quality education [31]. This include :

- Artificial intelligence helps universities for student acquisition by providing personalized assistance ubiquitously for targeted admission. Hence it can help higher education institutions to achieve higher enrolment and retention of students.

- It can empower institutions to pinpoint student issues earlier and intervene proactively.

- Artificial intelligence helps faculty members to spend more time with students on a deep level along with grading and supplying basic resources for students.

- Machine-learning algorithms could help model the ideal student profile, and recruit matching prospects with extreme precision.

- AI can be used to predict the likelihood of a student engaging with an email or to gain deeper insights into how prospects are talking about your institution on social media through intelligent sentiment analysis.

- Using AI, students can get assistance such as tutoring or advising based on their previous and predicted future academic performance.

- AI can recommend the next best actions for your recruiting, advising and alumni engagement teams based on intelligent insights and pattern recognition.

- AI can use information about a student from many campuses to guide hiring decisions by an employer.

- Across every department and throughout the lifecycle, AI-powered bots and assistants could take on more daily tasks, so staff can focus on what matters most: student success.

The subfield of artificial learning called machine learning that includes software which are capable of recognizing patterns, make predictions and apply them to situations which were not included in the initial design. AI automated solutions aim to find a new pedagogical philosophy that can help students achieve the set of skills required to live smartly in the twenty-first century [32]. Further, AI solutions are capable to identify our choices, preferences, movements, measuring strengths, and weaknesses, providing feedback, encouragement by providing customized news, alerts, so that take part to manage our lives [3339].

Virtual and augmented reality provides visual, immersive learning, and deep learning experiences. For example, engineering and architecture students can build digital structures virtually, history students can build ancient historical ruins, and marine biology students build ocean floors, forensic science students can build murder cases for searching clues, etc. for their immersive education. Virtual reality allows teachers to train their students by new way through virtual travel, create virtual art, and virtual dissects of animals and cadaver. Use of virtual reality into the curriculum will help teachers to supplement their talents with that of experts of virtual technology. When combined with social media, virtual reality has the potential to connect learners with the world and each other in ways never before realized. The classroom buildings, libraries, and shared academic spaces may someday provide physical grids or open sound stages designed for virtual interaction, where groups of students may take guided field trips to remote sites, interface with other cultures, or travel in time. The teacher may guide the conversation, identifying important 
concepts and features, and posing questions. Students with physical disabilities or financial disadvantages can get access to imagined places and experiences like never before. Students may also be able to experience things that can only be theorized about, such as journeying into a black hole or flying through a strand of DNA. But the real promise of virtual reality in higher education lies in its ability of interactive learning [40-41].

\section{RESEARCH AS DIFFERENTIATOR FOR CAMPUS BASED UNIVERSITIES :}

Due to the continued advent of information communication and computation technology and its applications in higher education offering models, online education is becoming more popular and it can be accessed ubiquitously. Such online education model and mass online open access courses (MOOC) is considered as a threat to campus-based education model [42]. It can be argued that by incorporating research in higher education model students get the opportunity to create new knowledge or interpret the existing knowledge in a new way, and it also allows the higher education institutions to customize the curriculum to individual students so that each student can do independent research by identifying individual issues [43]. Such customized research based higher education curriculum will differentiate the higher education institutions and allows them to effectively face the threats of massive online open access courses which are intended to provide mass education to the publics instead of customized education to individuals. Such customized higher education through customized research and publication increases the employability of the students based on their enhanced innovation ability to identify and solving many problems or analyses of many issues. Thus, adopting research in the higher education system allows the customization of the curriculum at UG and PG level which enable higher education institutions to survive against the threat of technology-supported MOOC model. There are few easy and introductory research methods that can be easily incorporated in undergraduate and postgraduate courses research curriculum. They are industry analysis, company analysis, case analysis, technology analysis, and patent analysis. Industry analysis and Company analysis are used in social science and management research [44-45]. Organization or company analysis is a powerful analysis technique to study various issues including strategies and innovations of organizations and companies which do any service or business [46]. Such a systematic analysis can be a research method for scholarly researchers in social science and business management related disciplines due to the reason that it can lead a new interpretation of existing knowledge in a systematic way.

Patent analysis is used in industrial research mainly in basic sciences, engineering, pharmacy, and health sciences to study patents already filed. Patent analysis is nothing but a detailed examination of the structure, elements, and various affecting factors of the patent. The patent analysis includes the process of breaking the invention or the process into smaller parts called elements or components in order to understand it in a better way. The analysis also helps to uncover and understand the cause-effect relationships and hence provides a basis for problem solving and decision making [47]. The analysis of the patents may lead to a better understanding of that subject which may lead to a better or new interpretation of the concepts related to that issue of the patent, and hence such analysis can be called as a method of research.

\section{INNOVATION IN UNIVERSITY RESEARCH :}

University research focuses on theoretical concept based research and generally end up with copyrighted scholarly publication and Industrial research is experimental research focuses on the development of new products or processes and generally end up with patent. Copyright and patents are two important intellectual property rights (IPR) a university can generate through innovations in researchbased curriculum and based on compulsory involvement of undergraduate and postgraduate students with the direction of faculty members in research activities. Further universities by 
redefining their objectives can focus more on research by starting research degree programmes leading to M.Phil., Ph.D. and post-doctorate research fellowships leading to the enhanced research community in the university [43]. As per our previous research findings, World-class university needs six essential infrastructures which include (1) impressive physical infrastructure, (2) useful digital infrastructure, (3) innovative academic teaching-learning infrastructure, (4) Intellectual property right (IPR) infrastructure, (5) Emotional infrastructure by stakeholders, and (6) Networked infrastructure [48]. Out of the above, creating IPR and emotional infrastructure for a university is the most difficult process and takes a considerably long time. IPR of a university is mainly divided into two types as copyright based IPR and Patent based IPR.

\subsection{Copyright based IPR}

Copyright is a right given by the country law to creators of literary, dramatic, musical and artistic works and producers of cinematograph films and sound recordings. Copyright includes inter alia, rights of reproduction, communication to the public, adaptation, and translation of the work. Copyright safeguards the rights of authors over their creations, articles, books, etc to protect creativity. Such protection provided by the copyright to the efforts of writers, artists, designers, etc. provides a supportive atmosphere to contribute more and motivates others also to create.

\subsection{Patent based IPR :}

A patent is an official right granted to the inventor to protect him from copying (making, using, selling, importing) the invention without his/her permission for a new product/process, for significant improvement in a system/item, for significantly improved process, and for new model/idea. Patents protect ideas, not just expressions of them. The main objective of patents is to provide the right to the holder to challenge any use of that invention by another party. Patentee thereby gets a temporary monopoly of exploitation by others for inventive industrial activities. Patents refer to an invention, whereas copyrights refer to the expression of an idea through an article, design, music drama, etc such as an artistic work. Though both copyright and patents are governed by different rules, but it is possible to look them under the same set of rules.

Universities as higher education institutes should formulate their strategy by providing annual performance-based incentives and fixing targets for annual IPR. Such a move will boost the competitiveness of researchers and increases their IPR contribution to university IPR infrastructure.

7.3 Author Centric Scholarly Publication for Copyright Based IPR :

In order to create more copyright IPR, universities should promote scholarly publications in open access journals and retaining the copyright with the researchers of the university. A new concept of retaining copyright with the author is going to be popular in future days. The Copyright Act, 1957 of Govt. of India protects original literature in the form of scholarly articles, dramatic, musical and artistic works and cinematograph films and sound recordings from unauthorized uses. Unlike the case with patents, copyright protects the expressions of concepts and not the ideas. There is no copyright protection for ideas, procedures, methods of operation or mathematical concepts. But the scholarly papers published as conceptual papers in philosophical sciences including management sciences, social sciences, etc can be protected and IPR can be generated by means registering copyright with the copyright registering organization in the country [49]. Table 7 gives an idea of different types of scholarly journals and their strategy of retaining the copyright. The table 7 also gives the characteristics of author cantered publication model.

Table 7 : Types of Journals for scholarly paper publication

\begin{tabular}{|l|l|l|l|l|l|}
\hline S.N. & Journal Type & Model & Characteristics & Copyright IPR \\
\hline 1 & $\begin{array}{l}\text { Closed Access } \\
\text { Subscription Type Journal }\end{array}$ & $\begin{array}{l}\text { Monopoly } \\
\text { business model }\end{array}$ & $\begin{array}{l}\text { Subscription to } \\
\text { library \& selling } \\
\text { articles online }\end{array}$ & $\begin{array}{l}\text { Copyright is with } \\
\text { Publisher }\end{array}$ \\
\hline
\end{tabular}


International Journal of Management, Technology, and Social

\begin{tabular}{|c|c|c|c|c|}
\hline 2 & $\begin{array}{l}\text { Open Access Payment } \\
\text { Type Journal }\end{array}$ & $\begin{array}{ll}\text { Author } & \text { payment } \\
\text { based } & \text { business } \\
\text { model } & \\
\end{array}$ & $\begin{array}{l}\text { Free access to } \\
\text { Libraries and public }\end{array}$ & $\begin{array}{l}\text { Copyright is with } \\
\text { Publisher }\end{array}$ \\
\hline 3 & Open Access Free Journal & $\begin{array}{l}\text { No payment by } \\
\text { author }\end{array}$ & $\begin{array}{l}\text { Free access to } \\
\text { Libraries and public }\end{array}$ & $\begin{array}{l}\text { Copyright } \\
\text { Publisher }\end{array}$ \\
\hline 4 & $\begin{array}{l}\text { Predatory } \\
\text { Journal }\end{array}$ & $\begin{array}{l}\text { Unethical } \\
\text { competitive } \\
\text { profit-oriented } \\
\text { Business model }\end{array}$ & $\begin{array}{l}\text { Open access to } \\
\text { Libraries \& Public }\end{array}$ & $\begin{array}{l}\text { Copyright } \\
\text { Publisher }\end{array}$ \\
\hline 5 & $\begin{array}{l}\text { Author Centric Open } \\
\text { Access Journal } \\
\text { (Ideal Publication model) }\end{array}$ & $\begin{array}{l}\text { Non-profit charity } \\
\text { model }\end{array}$ & $\begin{array}{l}\text { Open access to } \\
\text { Libraries \& Public }\end{array}$ & $\begin{array}{l}\text { Copyright is } \\
\text { Author }\end{array}$ \\
\hline
\end{tabular}

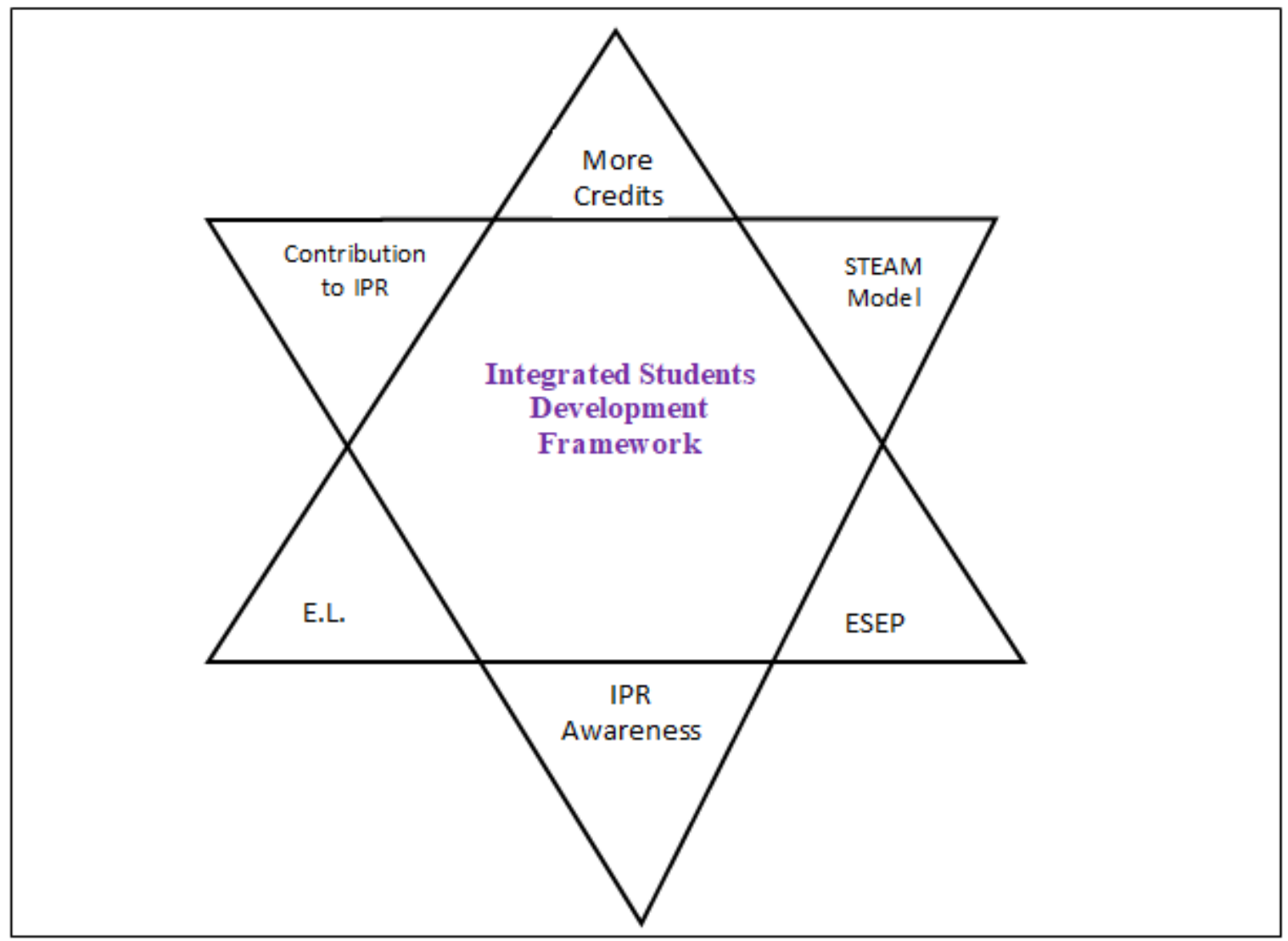

Fig. 1: Integrated Student development Framework for effective education [52]

The predatory journals are following unethical publication practices using a competitive profitoriented business model. They are unethical in terms of plagiarism and review. They do not consider the important attributes of scholarly articles like novelty/new knowledge/new analysis \& interpretation. Some of the characteristics of predatory journals are : many articles with same page numbers, uneven publication, no ISSN number, publishing Conference Proceedings as journal volumes, wrongly claiming index, not reachable to search engines, wrong DOI, 100\% paper acceptance, No systematic format, etc. However, author centric (or researcher centric) open access journals are managed by universities or other charitable institutions and do not charge an article processing fee to the authors for review 
and publication. They publish scholarly articles as open access articles which are reachable globally for free and keeps the copyright with authors [50-51]. Universities can develop a policy to promote open access publication which can enhance citations to the articles due to its ubiquitously free accessibility and intellectual property (IPR) by retaining copyrights with the researchers. Such open access publications can be further promoted by the authors by uploading them in many freely available popular research networks.

\subsection{Student Centric Curriculum for Patent} Based IPR :

While offering any UG, or PG program in universities, the curriculum and pedagogy plays an important role. Programs with futuristic curriculum and attractive pedagogy can realize the objective of higher education by providing suitable knowledge, employable skills, and experience so that both confidence and competency of the students should be upgraded to the industry expectations. Recently we have developed a conceptual model on student centric curriculum to increase their employability based on innovativeness. This integrated student development framework is based on STEAMEmployability Model (STEAM stands for Science, Technology, Engineering, Arts \& design, and Mathematics) with a focus on experimental learning and IPR generation. The model is also represented in the form of a block diagram as shown in figure 1 [52].

The integrated Student development framework is focused to generate new knowledge, new skills, new experience through hard and dedicated learning model which is based on (1) More credits to cover learning on continuously increasing information with time, (2) STEAM focus in curriculum planning, (3) Employability skills enhancement program (ESEP) features, (4) Creating intellectual property awareness through compulsory patent analysis in specialized fields, (5) Experienced learning (EL) by means of industry oriented internship, and (6) Compulsory contribution to IPR either through copyright or through patent filing to qualify for the award of degree. Universities which formulate strategy to implement such integrated student development framework by having collaboration with industries are capable to reach excellence.

\section{HOW TO PROMOTE RESEARCH \& INNOVATIONS IN UNIVERSITIES :}

Setting the objective of the university as research focus is the preliminary requirement and then the universities focus on supporting research based education at undergraduate, and postgraduate level. Universities also increase research fellowships and research faculties to offer research degrees leading to Ph.D. qualification. Table 8 lists top ten world universities and it is seen that both public and private universities in the list have research as their objective. Indian universities both in public sector and private sector should redefine their objective as research universities and formulate their strategies to identify and recruit research interested faculties and students and develop their curriculum as research focussed. The annual research productivity of individual faculty members in all levels should be calculated using any appropriate model. For example, our recently developed ABC model of annual research productivity allows to measure annual research performance of faculty members in universities [53-55]. ABC model of annual research productivity framework allows to calculate individual and institutional (university) research index and weighted research index. ABC model consists of four institutional parameters identified as number of Articles published in peer reviewed journals (A), number of Books published (B), number of Case studies/patents/ book Chapters (C) published, and the number of full time Faculty members (F) in that higher education institution during a given time of observation. Based on this model one can implement a strategy to promote research productivity in universities [56-57].

Table 8 : Objectives of Top Ten World Universities (as ranked in Times Higher Education ranking 2020)

\begin{tabular}{|l|l|l|l|}
\hline Rank & University name & Country & Type \& Objective \\
\hline 1 & University of Oxford & United Kingdom & Collegiate Research University \\
\hline 2 & California Institute of & United States & Private Research University \\
\hline
\end{tabular}




\begin{tabular}{|l|l|l|l|}
\hline & Technology & & \\
\hline 3 & University of Cambridge & United Kingdom & $\begin{array}{l}\text { Collegiate Public Research } \\
\text { University }\end{array}$ \\
\hline 4 & Stanford University & United States & Private Research University \\
\hline 5 & Massachusetts Institute of & United States & Private Research University \\
\hline 6 & Princeton University & United States & Private Research University \\
\hline 7 & Harvard University & United States & Private Research University \\
\hline 8 & Yale University & United States & Private Research University \\
\hline 9 & University of Chicago & United States & Private Research University \\
\hline 10 & Imperial College London & United Kingdom & Public Research University \\
\hline
\end{tabular}

The universities must take some of the measures to promote research and innovation using their autonomy. This includes compulsory research components in the curriculum, performancebased faculty compensation, annual faculty ranking based on individual annual faculty research index, promotions are based on research performance, etc. Theory of accountability (Theory A) [58 - 64] is best suitable for inspiring and motivating the faculty members and other researchers to get their maximum contribution both individually and team wise for research productivity. The essential elements of Accountability Theory (Theory A) include (1) Systematic planning, (2) Target setting for individuals and groups, (3) Motivation through continuous follow-up, (4) Developing working strategies, (5) Fixing responsibility, (6) Showing role model, (7) Monitoring \& Guiding to reach the goal, and (8) Accountability either positive or negative depending on the outcome. Theory A can be effectively implemented in universities by following a framework consisting of collective identification of the need, collective goal setting, collective responsibility, collective monitoring, and collective accountability. The choice of work strategy, motivation, and developing internal role models are tools for accomplishing the research objective [65-66]. Vice-chancellor and Deans of the university should be role models for young researchers through their continuous research contribution. Promoting collaborative research with other higher education institutions and industries through an organizational research policy to increase the research and innovation of the university and will help the university to march towards excellence through reimaging its position by fully utilizing its autonomy [67-68].

\section{SOME RECOMMENDATIONS FOR ACHIEVING EXCELLENCE AND REIMAGING UNIVERSITIES THROUGH RESEARCH BASED INNOVATION :}

Based on the above arguments the following postulates are recommended to achieve excellence in research and innovation to reimage universities :

(1) Redefine the objective of the university as a research university so that focus on both teaching and research is possible.

(2) Use the university autonomy to innovate the curriculum as futuristic and industry oriented.

(3) Promote choice based higher education system by using academic autonomy with more options on research and industry internship to make higher education as research centric.

(4) Develop student centric curriculum by adding employability skill enhancement subjects and experimental learning models to increase graduate employability.

(5) Use of ICCT underlying technologies in teaching, learning and innovation process as they are more effective in engaging the students in academic and research activities.

(6) University curriculum should be designed by keeping the overall development of a student and the current practice is to consider the STEAM model.

(7) Promote a suitable delivery model including curriculum, pedagogy, assessment using suitable technology in higher education to fulfill the desires of the technology-savvy present generation $\mathrm{Z}$ and future generation $\mathrm{A}$.

(8) Planning and implementation of Integrated 
Student development Framework for all-round effective education and student contribution to copyright and patent based IPR are essential for university excellence.

(9) Research focussed higher education provides the opportunity to customize it to individuals so that the students can be differentiated among each other so that the threat of MOOC to campus based universities can be eliminated. This provides sustainability to campus based higher education systems considerably for a long period.

(10) Promote the authors cantered scholarly publication model to retain the copyright of scholarly publications and for global reach.

(11) ABC model and Theory of Accountability (Theory A) helps to enhance the research productivity of universities and universities should use their autonomy to implement them.

(12) Involving all stakeholders of the university optimally in the process of promoting research and innovation is the need of the hour and is critical to reimage the universities towards world-class universities.

\section{CONCLUSION :}

Universities, being major authorities of promoting higher education have the responsibility in providing innovative liberal education to attract more students to higher education levels with a goal to improve the gross enrolment ratio. The innovation in higher education is accomplished by offering an attractive curriculum that is futuristic by predicting the effect of future technology on education and other industries. There are two ways of innovations observed in HEI which include (1) Technology based innovation, and (2) Research based innovation. Such innovations in the education system can be realized by involving all the stakeholders of universities and by using all its resources optimally. Technology based innovations give rise to new pedagogy, new models of teaching, new method of assessment, and improvements in evaluation and research based innovations enhances creative thinking and problem solving in an optimum way so that students objective of acquiring knowledge \& new knowledge, skills \& new skills, and experience based competency and confidence building can be fulfilled. Through proper plan and developing appropriate strategies using their autonomy, Universities are trying re-define their education models including, suitable subject identification, developing and offering industry related curriculum, effective teaching - learning methodologies including suitable customized pedagogy and use of educational technology to boost the confidence and innovative thinking abilities of graduates. It is suggested that faculty and student-centred approach on quality research and innovation in universities will effectively contribute to the objectives of the universities and their quest for excellence and hence support to survivability, sustainability, differentiability, monopoly, or growth \& prosper to reimage the universities. Such improvements in student centred higher education should attract more youngsters to higher education system to increase the GER to proposed $40 \%$ at least by the year 2030.

\section{REFERENCES :}

[1] Aithal, P. S., Suresh Kumar P. M. (2015). Black Ocean Strategy - A Probe into a New type of Strategy used for Organizational Success. GE International Journal of Management Research, 3(8), 45 - 65. DOI : http://doi.org/10.5281/zenodo.163423.

[2] Hou Shengtian (2007). Green ocean strategy: Obtaining sustainable competitive advantage, Beijing: Tsinghua University Press, pp. 183-197.

[3] Porter, M. E. (1997). Competitive strategy. Measuring Business Excellence, 1(2), 1217.

[4] Kim, W. C., \& Mauborgne, R. (2005). Blue ocean strategy. California Management Review, 47(3), 105-121.

[5] Aithal, P. S. (2016). The concept of Ideal Strategy \& its realization using White Ocean Mixed Strategy. International Journal of Management Sciences and Business Research (IJMSBR), 5(4), 171179.DOI http://doi.org/10.5281/zenodo.161108. 
[6] Ramakrishna, S. (2015). Strategies for the Universities to be Locally Engaged while Globally Visible. Asian Journal of Innovation \& Policy, 4(3), 271-287. DOI: http://dx.doi.org/10.7545/ajip.2015.4.3.271.

[7] Aithal, P. S., Anil Kumar, Madhushree, \& Revathi R. (2018). Investigation of Business Strategies in Higher Education Service Model of Selected Private Universities in India. International Journal of computational Research and Development (IJCRD), 3(1), 2018, 77-100. DOI http://doi.org/10.5281/zenodo.1209910.

[8] Suresh, S. (2015). Research Universities, Innovation, and Growth. ResearchTechnology Management, 58(6), 19-23.

[9] Perkmann, M., \& Walsh, K. (2007). University-industry relationships and open innovation: Towards a research agenda. International journal of management reviews, 9(4), 259-280.

[10] Rip, A. (2011). The future of research universities. Prometheus, 29(4), 443-453.

[11] Quinsee, S. (2011). How can we create the university of the future?. Learning at City Journal, 1(1), 8-22.

[12] Hariri, A., \& Roberts, P. (2015). Adoption of innovation within universities: Proposing and testing an initial model. Creative Education, 6(02), 186.

[13] Ospina-Delgado, J., \&Zorio-Grima, A. (2016). Innovation at universities: A fuzzyset approach for MOOCintensiveness. Journal of Business Research, 69(4), 1325-1328.

[14] Abdul Razak, A., Murray, P. A., \& Roberts, D. (2014). Open innovation in universities: The relationship between innovation and commercialisation. Knowledge and Process Management, 21(4), 260-269.

[15] Salter, D. J. (2013). Cases on quality teaching practices in higher education. Journal of Cases on Information Technology, 15(2), 72-74.
[16] Sosteric, M., Gismondi, M., \&Ratkovic, G. (1998). The university, accountability, and market discipline in the late 1990s. Electronic Journal of Sociology, 3(3), 1-16.

[17] Kusumastuti, D. (2013). Strategic Direction toward Internationalization Business and Management Education. International Journal of Trade, Economics and Finance, 4(3), 156.

[18] O’Leary, M. \& Wood, P. (2019). Reimagining teaching excellence: why collaboration, rather than competition, holds the key to improving teaching and learning in higher education. Educational Review, 71(1), 122-139.

[19] Freytag, C. E. (2008). Reimagining excellence in inclusive education: Transforming edict to ethic. Journal of Education and Christian Belief, 12(2), 129143.

[20] Lewis, N. \& Shore, C. (2019). From unbundling to market making: reimagining, reassembling and reinventing the public university. Globalisation, Societies and Education, 17(1), 11-27.

[21] Kek, M. Y. \&Huijser, H. (2015). 21st Century Skills: Problem Based Learning and the University of the Future. In Third 21st Century Academic Forum Conference: Facilitating, Fostering, and Harnessing Innovation to Meet Key Challenges of the 21st Century, 6(1), 406-416.

[22] Shubhrajyotsna Aithal \& Aithal, P. S. (2018). The Realization Opportunity of Ideal Energy System using Nanotechnology Based Research and Innovations. International Journal of Advanced Trends in Engineering and Technology, 3(2), 1-15. DOI http://doi.org/10.5281/zenodo.2531876.

[23] Aithal, P. S. \&Madhushree, L. M. (2019). Information Communication \& Computation Technology (ICCT) as a Strategic Tool for Industry Sectors. International Journal of Applied 
Engineering and Management Letters (IJAEML), 3(2), 65-80. DOI: http://doi.org/10.5281/zenodo.3549423.

[24] Aithal, P. S. \&Shubhrajyotsna Aithal (2019). Management of ICCT underlying Technologies used for Digital Service Innovation. International Journal of Management, Technology, and Social Sciences (IJMTS), 4(2), 110-136. DOI : http://doi.org/10.5281/zenodo.3591139.

[25] Lee, M. K., Cheung, C. M., \& Chen, Z. (2005). Acceptance of Internet-based learning medium: the role of extrinsic and intrinsic motivation. Information \& management, 42(8), 1095-1104.

[26] Barnes, K., Marateo, R. C., \& Ferris, S. P. (2007). Teaching and learning with the net generation. Innovate: Journal of Online Education, 3(4).

[27] Kolikant, Y. B. D. (2010). Digital natives, better learners? Students' beliefs about how the Internet influenced their ability to learn. Computers in Human Behavior, 26(6), 1384-1391.

[28] Desai, S. P., \&Lele, V. (2017). Correlating internet, social networks and workplace-A case of Generation Z students. Journal of Commerce and Management Thought, 8(4), 802-815.

[29] Seemiller, C., \& Grace, M. (2017). Generation Z: Educating and engaging the next generation of students. About Campus, 22(3), 21-26.

[30] Madhushree, L. M., Pradeep M. D.\& Aithal, P. S. (2019). Boosting Education through Mobile Technology in India Study with reference to Generation Z. International Journal of Applied Engineering and Management Letters (IJAEML), 3(2), 96-105. DOI: http://doi.org/10.5281/3597588.

[31] Garrison, D. R., \& Akyol, Z. (2009). Role of instructional technology in the transformation of higher education. Journal of Computing in Higher Education, 21(1), 19.
[32] Popenici, S.A.D., Kerr, S. (2017). Exploring the impact of artificial intelligence on teaching and learning in higher education. RPTEL, 12, 22. DOI : https://doi.org/10.1186/s41039-017-0062-8.

[33] Popenici, S. A., \& Kerr, S. (2017). Exploring the impact of artificial intelligence on teaching and learning in higher education. Research and Practice in Technology Enhanced Learning, 12(1), 22.

[34] Chassignol, M., Khoroshavin, A., Klimova, A., \&Bilyatdinova, A. (2018). Artificial Intelligence trends in education: a narrative overview. Procedia Computer Science, 136, 16-24.

[35] Colchester, K., Hagras, H., Alghazzawi, D., \&Aldabbagh, G. (2017). A survey of artificial intelligence techniques employed for adaptive educational systems within elearning platforms. Journal of Artificial Intelligence and Soft Computing Research, 7(1), 47-64.

[36] Roll, I., \& Wylie, R. (2016). Evolution and revolution in artificial intelligence in education. International Journal of Artificial Intelligence in Education, 26(2), 582-599.

[37] Edwards, B. I., \& Cheok, A. D. (2018). Why not robot teachers: artificial intelligence for addressing teacher shortage. Applied Artificial Intelligence, 32(4), 345-360.

[38] Bajaj, R., \& Sharma, V. (2018). Smart Education with Artificial Intelligence based Determination of Learning Styles. Procedia computer science, 132, 834-842.

[39] Luckin, R. (2017). Towards artificial intelligence-based assessment systems. Nature Human Behaviour, 1(3), 13.

[40] Lee, K. (2012). Augmented reality in education and training. TechTrends, 56(2), 13-21.

[41] Kavanagh, S., Luxton-Reilly, A., Wuensche, B., \&Plimmer, B. (2017). A 
systematic review of Virtual Reality in education. Themes in Science and Technology Education, 10(2), 85-119.

[42] Shubhrajyotsna Aithal \&Aithal, P. S.(Jan 2019). How to Customize Higher Education at UG \& PG levels using Patent Analysis \& Company Analysis as New Research Methods in Technology, In Information Technology and Education, Challenges and Opportunities of Smarter Learning Systems,New Delhi Publishers, India. Chapter 3, pp. 25-59. ISBN: 978-9388879-13-2.

DOI https://doi.org/10.5281/zenodo.3593900.

[43] Aithal, P. S. \& Suresh Kumar, P. M. (2017). Challenges and Opportunities for Research \& Publications in Higher Education. International Journal of Scientific Research and Modern Education (IJSRME), 2(1), 42-49. DOI: http://dx.doi.org/10.5281/zenodo.400 $\underline{619}$.

[44] Aithal, P. S. (2017). Industry Analysis The First Step in Business Management Scholarly Research. International Journal of Case Studies in Business, IT and Education (IJCSBE), 2(1), 1-13. DOI: http://dx.doi.org/10.5281/zenodo.810347.

[45] Aithal, P. S., (2017). Company Analysis The Beginning Step for Scholarly Research. International Journal of Case Studies in Business, IT and Education (IJCSBE), 1(1), 1-18.

DOI: http://dx.doi.org/10.5281/zenodo.573769.

[46] Aithal, P. S. (2017). An Effective Method of Developing Business Case Studies based on Company Analysis, International Journal of Engineering Research and Modern Education (IJERME), 2(1), 16-27. DOI: http://dx.doi.org/10.5281/ZENODO.4 $\underline{00579}$.

[47] Aithal P. S. \&Shubhrajyotsna Aithal, (2018). Patent Analysis as a New Scholarly Research Method. International Journal of Case Studies in Business, IT, and Education (IJCSBE), 2(2), 33-47. DOI:http://dx.doi.org/10.5281/zenodo.1404
184.

[48] Aithal, P. S., \& Aithal, Shubhrajyotsna. (2019). Building World-Class Universities: Some Insights \& Predictions. International Journal of Management, Technology, and Social Sciences (IJMTS), 4(2), 13-35. DOI: http://doi.org/10.5281/zenodo.3377097.

[49] Aithal, P. S. (2016). Innovations in Student Centric Learning - A Study of Top Business Schools in India. International Journal of Engineering Research and Modern Education (IJERME), 1(1), 298306.

DOI: http://doi.org/10.5281/zenodo.161045.

[50] Aithal, P. S. \&Shubhrajyotsna Aithal (2019). Researcher Centric Scholarly Publication and Research Journals Classification - New Insight based Model. International Journal of Case Studies in Business, IT, and Education (IJCSBE), 3(2), 91-104. DOI: http://doi.org/10.5281/zenodo.3591033.

[51] Aithal, P. S., and Shubhrajyotsna Aithal, (2016). Scholarly Publishing : Why Smart Researcher Hesitate to Publish in/with Top Ranking Journals/Publishers,. International Journal of Current Research and Modern Education (IJCRME), 1(1), 829-845. DOI: http://doi.org/10.5281/zenodo.62019.

[52] Aithal, P. S., \& Aithal, Shubhrajyotsna. (June 2019). Innovation in B.Tech. Curriculum as B.Tech. (Hons) by integrating STEAM, ESEP \& IPR features. International Journal of Case Studies in Business, IT, and Education (IJCSBE), 3(1), 56-71. DOI: http://doi.org/10.5281/zenodo.3248630. ISSN : 2581-6942.

[53] Aithal, P. S. \& Suresh Kumar, P.M., (2016). ABC Model of Research Productivity and Higher Educational Institutional Ranking. International Journal of Education and Management Engineering (IJEME), 6(6), 74-84. DOI: http://doi.org/10.5815/ijeme.2016.06.08.

[54] Aithal, P. S., Shailashree V. T. \& Suresh 
Kumar P. M., (2016). Analysis of ABC Model of Annual Research Productivity using ABCD Framework. International Journal of Current Research and Modern Education (IJCRME), 1(1), 846-858. DOI : http://doi.org/10.5281/zenodo.62022.

[55] Aithal, P. S. (2016). Study of Research Productivity in World Top Business Schools. International Journal of Engineering Research and Modern Education (IJERME), 1(1), 629-644. DOI : http://doi.org/10.5281/zenodo.160969.

[56] Aithal, P. S. (2016). How to Increase Research Productivity in Higher Educational Institutions -SIMS Model. International Journal of Scientific Research and Modern Education (IJSRME), 1(1), 447-458. DOI : http://doi.org/10.5281/zenodo.161037.

[57] Aithal, P. S. (2016). Study of Annual Research Productivity in Indian Top Business Schools. International Journal of Scientific Research and Modern Education (IJSRME), 1(1), 402-414. DOI : http://doi.org/10.5281/zenodo.161041.

[58] Aithal, P. S. and P. M. Suresh Kumar. (2016). Organizational Behaviour in $21^{\text {st }}$ Century - Theory A for Managing People for Performance. IOSR Journal of Business and Management (IOSR-JBM), 18(7), 126134. DOI: http://doi.org/10.9790/487X180704126134.

[59] Aithal, P. S. \& P. M. Suresh Kumar, (2016). Comparative Analysis of Theory X, Theory Y, Theory Z, and Theory A for Managing People and Performance. International Journal of Scientific Research and Modern Education (IJSRME), 1(1), 803-812.

DOI:

http://doi.org/10.5281/zenodo.154600

[60] Aithal, P. S. \& Suresh Kumar, P. M. (2016). Theory A for Optimizing Human Productivity. IRA-International Journal of Management \& Social Sciences, 4(3), 526535. DOI http://dx.doi.org/10.21013/jmss.v4.n3.p2.
[61] Aithal, P. S. \& Suresh Kumar, P. M. (2016). CCE Approach through ABCD Analysis of 'Theory A' on Organizational Performance. International Journal of Current Research and Modern Education (IJCRME), 1(2), 169-185. DOI: http://dx.doi.org/10.5281/zenodo.164 704.

[62] Aithal, P. S. (2016). Inspiring through SelfContribution - An Analysis of How Active the Indian Top Business School Directors in Research \& Publications. International Journal of Engineering Research and Modern Education (IJERME), 1(2), 137 154.

DOI: http://dx.doi.org/10.5281/zenodo.164690.

[63] Aithal, P. S. (2016). Excellence in Individual Research \& Publications : Examining the Active Role of Role models (Deans) of World Top Business Schools. International Journal of Engineering Research and Modern Education (IJERME), 1(2), 179-199. DOI: http://dx.doi.org/10.5281/zenodo.192 $\underline{881}$.

[64] Aithal, P. S. \& Suresh Kumar, P. M. (2016). Application of Theory A on ABC Model to enhance Organizational Research Productivity in Higher Education. International Journal of Advanced Trends in Engineering and Technology (IJATET), 1(1), 142-150. DOI : http://doi.org/10.5281/zenodo.240646.

[65] Aithal, P. S. \& Suresh Kumar P. M. (2017). Integrating Theory A and Six Thinking Hats for Improved Organizational Performance. International Journal of Applied Engineering and Management Letters (IJAEML), 1(2), 66-77. DOI: http://dx.doi.org/10.5281/zenodo.1045417.

[66] Aithal, P. S. \& Suresh Kumar P. M. (2017). Interconnecting Theory A and ABC Model of Organizational Performance. International Journal of Management, Technology and Social Sciences (IJMTS), Srinivas Publishers, 1(1), 1-13. DOI: http://dx.doi.org/10.5281/zenodo.268598. 
[67] Aithal, P. S. \&Shubhrajyotsna Aithal (2019). Autonomy for Universities Excellence - Challenges and Opportunities. International Journal of Applied Engineering and Management Letters (IJAEML), 3(2), 36-50. DOI: http://doi.org/10.5281/zenodo.3464710.

[68] Aithal P. S. \& Suresh Kumar P. M. (2019). Autonomy in Higher Education - Towards an Accountability Management Model. International Journal of Management \& Development, 6(10), 166-175. DOI : https://doi.org/10.5281/zenodo.3594255. 